\title{
The use of hormonal drugs to increase the reproductive function of animals in the agro- industrial complex
}

\author{
Natalia Malakhova *, Olga Piskunova and Andrey Lishchuk \\ FSBEE HE Orel State Agrarian University named after N. V. Parakhin, Faculty of Biotechnology and \\ Veterinary Medicine, Generala Rodina 69, Orel, Russia
}

\begin{abstract}
An increase in the productivity of animals is possible only with the use of deep knowledge of the relationship of the organism with the environment. New technologies for the reproduction, management and raising of animals are inevitably accompanied by industrial stresses, which create the preconditions for a weakening of the general condition of the body and a decrease in hormonal status, which leads to disorder of the ovulatory response of the ovaries, to decrease of rate fertilization and fertility of animals, and a decrease in the profitability of the industry. The goal of research is to analyze the reasons for the low fertility of animals, methods and ways of its correction for the formation of a full-rate sexual cycle.
\end{abstract}

\section{Introduction}

The growth in the production of livestock products, along with feeding, care and maintenance of animals, primarily depends on the level of organization of herd reproduction. Therefore, in each farm a base to accelerate the intensification of the reproduction of productive animals is created [1,9].

In spite of significant achivements in veterinary science in the field of physiology and pathology of animal reproduction, the genetically determined potential fertility of cattle and pigs, due to a number of objective and subjective circumstances, is far from being fully realized, which is largely associated with disoder of reproductive function. Realization of the genetic potential of productivity can be carried out only under the condition of a high level of reproductive function of the breeding stock and its productive longevity.

The importance of the problem has caused the necessity to summarize the latest scientific data and best practices on the main issues of reproduction of breeding stock assessment and selection of animals in the conditions of industrial technology for the production of livestock products, the effectiveness of different rates of annual renewal of breeding stock, directional herdreplacement, improving organizational methods to increase the reproductive capacity of animals. $[4,7]$.

\footnotetext{
*Corresponding author: malahova-n@ mail.ru
} 
The results of clinical and experimental studies on laboratory and, later, on farm animals have shown the great importance of hormones in the regulation of physiological functions, as well as the possibility of their use for directed changes in metabolism, productivity and fertility of animals $[5,6,11]$.

In the conditions of industrial complexes for the production of livestock products, there is a lack of heat in the breeding stock, which is associated with a violation of the technology of their raising, insufficient vitamin nutrition of animals, lack of insolation, exercise and other reasons $[2,10]$.

In addition, it is known that chronic stress of animals under industrial technology (rearrangement of animals, lack of living space, lack of walking, occupational noises, geopathogenic zones, etc.) lowers the secretion of luteinizing hormone (LH), which leads to disruption of the ovulatory response of the ovaries (atresia preovulatory follicles, prolongation of ovulation in time, a decrease in the number of ovulating follicles) [8].

In accordance with the purpose of the research, the following tasks were identified in this work:

- to determine the reasons for the absence of a full-rate sexual cycle in sterile cows and pigs;

- to find out the state of morpho-biochemical, hormonal parameters of the organism and changes in the status of females with reduced fertility function;

- to study the effectiveness of using a synthetic analogue of the releasing hormone "Surfagon" and an analogue of prostaglandin - "Estrofantin" (OvSynch scheme).

- to compare the effectiveness of hormonal stimulation of the sexual function of cows, using scheme no. 1 OvSynch and scheme no. 2 SelectSynch.

- to study the effectiveness of the use of drugs "PG 600" and "Follimag" to stimulate reproductive function in sows;

- the effectiveness of hormonal stimulation of the sexual function of sows, using the preparations "PG 600" and "Follimag".

\section{Material and methods}

The material for the study was black-and-white cows at the age of 3-5 years, the first 2 months after calving, belonging to the farm of OOO Meshcherino, the Plavsk district, the Tula region, as well as sows of the large white breed at the age of 1-1.5 years, the first month after farrowing, belonging to the pig breeding complex of OOO Znamenskiy SGTs, the Liveny district, the Orel region.

Diseases were diagnosed by rectal method and by ultrasound examination. Ultrasound examination was performed on a DRAMINSKI iScan Standard apparatus (Poland).

At rectal palpation, the ovaries in sterile sows and cows with acyclia were small and dense, while no follicles and yellow bodies were found in the ovaries. Echographic examination showed that the ovaries in a hypofunctional state do not have an echogenic formation.

To study the homeostasis of sterile animals, blood tests, which were taken from the jugular vein into vacuum tubes in the morning before feeding the animals, were carried out. The blood tests of the animals of the first experimental and the second experimental groups were taken before and at the end of the experiment and they were examined according to the following blood values: the content of carotene, calcium, phosphorus, determination of reserve alkalinity, the amount of sugar and total protein.

Also, before and at the end of the experiment, the blood of the experimental groups was tested for hormonal status. The study was carried out according to the following blood values: FSH, LH, progesterone, estradiol, and testosterone. 


\section{Results and discussion}

Analysing the results of the blood test of cows, it should be noted that the content of calcium, phosphorus, sugar, reserve alkalinity are at the lower limit of the physiological norm, and the content of carotene, total protein in some cows does not reach it. This phenomenon is primarily due to the fact that the content of digestible protein and carotene is in deficiency, which is associated with long-term and improper storage of feed

The results of a biochemical study of blood serum are shown in Table 1.

Table 1. The result of a blood test of cows before treatment.

\begin{tabular}{|c|c|c|c|c|c|c|}
\hline Values & $\begin{array}{c}\text { Carotene } \\
(\mathbf{m g r} \%)\end{array}$ & $\begin{array}{c}\text { FSH } \\
(\mathbf{m g} \%)\end{array}$ & $\begin{array}{c}\text { Total Protein } \\
(\mathbf{m g} \%)\end{array}$ & $\begin{array}{c}\text { Calcium } \\
(\mathbf{m g} \%)\end{array}$ & $\begin{array}{c}\text { Phosphorus } \\
(\mathbf{m g} \%)\end{array}$ & $\begin{array}{c}\text { Sugar } \\
(\mathbf{m g} \text { \%) }\end{array}$ \\
\hline $\begin{array}{c}\text { At an average } \\
\text { on group }\end{array}$ & 0,402 & 462 & 6,00 & 10,5 & 4,7 & 40,4 \\
\hline $\begin{array}{c}\text { Reference } \\
\text { range }\end{array}$ & $0,416-2,208$ & $450-540$ & $7,2-8,6$ & $10,0-12,5$ & $4,5-6,5$ & $40-60$ \\
\hline
\end{tabular}

According to the results of the analysis of a biochemical study of blood serum, it can be assumed that one of the reasons for ovarian hypofunction is a metabolic disorder in the animal's body, as well as the occurrence a stress state associated with their more intensive exploitation in highly productive cows.

Selection of dairy cattle primarily is aimed at productivity increasing. The mammary gland is much better developed in high-yielding cows than in medium- and low-yielding cows. The amount of nutrients circulating in the blood and their balance limits the milk yield. The amount of these substances depends on their dietary intake and stocks in the body [3].

With a decrease in fatness, the hypothalamus reduces the production of gonadotropinreleasing hormone, which regulates the production of sex hormones in the pituitary gland. As a result, cows do not come into heat for a long time, or their follicle maturation and ovulation are delayed.

In this regard, a study of the blood of cows for the content of follicle-stimulating, luteinizing hormones, progesterone, estradiol, and testosterone was carried out.

According to table 2, the level of follicle-stimulating, luteinizing hormones, progesterone, testosterone in the blood of cows with ovarian hypofunction is below the physiological norm.

Table 2. Results of blood tests of cows diagnosed with ovarian hypofunction for hormonal status.

\begin{tabular}{|c|c|c|c|c|c|}
\hline Values & $\begin{array}{c}\text { FSH } \\
(\mathbf{m I U} / \mathbf{L})\end{array}$ & $\begin{array}{c}\text { LH } \\
(\mathbf{m I U} / \mathbf{L})\end{array}$ & $\begin{array}{c}\text { Progesterone } \\
(\mathbf{n M} / \mathbf{L})\end{array}$ & $\begin{array}{c}\text { Estradiol } \\
(\mathbf{n M} / \mathbf{L})\end{array}$ & $\begin{array}{c}\text { Testosterone } \\
(\mathbf{n M} / \mathbf{L})\end{array}$ \\
\hline $\begin{array}{c}\text { At an average } \\
\text { on group }\end{array}$ & $9,4 \pm 0,25^{*}$ & $9,5 \pm 0,44$ & $1,7 \pm 0,12^{*}$ & $108,4 \pm 1,05^{*}$ & $0,85 \pm 0,03$ \\
\hline $\begin{array}{c}\text { Reference } \\
\text { range }\end{array}$ & $11,4-15,0$ & $10-12$ & $2,0-3,0$ & $110-116$ & $0,9-1,5$ \\
\hline
\end{tabular}

* Statistically significant at level of significance of $p<0.05$

The blood tests showed and made it possible to conclude that the level of metabolism in cows in the second half of the winter-stall period is at the lower limit of the physiological norm, which is due to the level of animals feeding in the winter-stall period.

Studies of the hormonal status of sterile sows also indicate a decrease in the level of hormones in the blood, which play an important role in the formation of the sexual cycle of pigs. 
According to the results of serum tests of sows with ovarian hypofunction, a significant (by 22.69\%) decrease in the level of follicle-stimulating hormone was established. Values of luteinizing hormone, progesterone, and estradiol were below the physiological norm by $8.03 \% ; 9.81 \% ; 10.97 \%$ and $10.0 \%$, respectively. The testosterone content was within the reference range.

Table 3. The results of the serum tests of pigs with ovarian hypofunction for hormonal status.

\begin{tabular}{|c|c|c|c|c|c|}
\hline $\begin{array}{c}\text { No of the } \\
\text { group }\end{array}$ & $\begin{array}{c}\text { FSH } \\
(\mathbf{m I U} / \mathbf{L})\end{array}$ & $\begin{array}{c}\text { LH } \\
(\mathbf{m I U} / \mathbf{L})\end{array}$ & $\begin{array}{c}\text { Progesterone } \\
(\mathbf{n M} / \mathbf{L})\end{array}$ & $\begin{array}{c}\text { Estradiol } \\
(\mathbf{n M} / \mathbf{L})\end{array}$ & $\begin{array}{c}\text { Testosterone } \\
(\mathbf{n M} / \mathbf{L})\end{array}$ \\
\hline $\begin{array}{c}\text { The first } \\
\text { group }\end{array}$ & $10,4 \pm 1,01$ & $8,54 \pm 0,05^{*}$ & $32,86 \pm 1,11^{*}$ & $74,32 \pm 0,89^{*}$ & $0,85 \pm 0,02^{*}$ \\
\hline $\begin{array}{c}\text { The } \\
\text { second } \\
\text { group }\end{array}$ & $10,28 \pm 1,05^{*}$ & $8,40 \pm 0,01^{*}$ & $33,08 \pm 1,03$ & $73,01 \pm 1,06^{*}$ & $0,89 \pm 0,01^{*}$ \\
\hline $\begin{array}{c}\text { Reference } \\
\text { range }\end{array}$ & $12-15$ & $9-13$ & $34-36$ & $76-89$ & $0,9-1,2$ \\
\hline
\end{tabular}

${ }^{*}$ Statistically significant at level of significance of $p<0.05$

Stimulation of sexual function in cows was carried out using a synthetic analogue of the releasing hormone "Surfagon" and an analogue of prostaglandin PGF2 $\alpha$ "Estrofantin" according to two treatment regimens: OvSynch (GnRH - PGF2 $\alpha-$ GnRH) and SelectSynch $(\mathrm{GnRH}-\mathrm{PGF} 2 \alpha)$ [5].

The cows of the first experimental group were administrated intramuscularly with a synthetic analogue of the gonadotropic releasing hormone "Surfagon" in a dose of $2 \mathrm{ml}$, and after 7 days - the analogue of prostaglandin PGF2 $\alpha$ "Estrofantin". Then, after 2 days, the releasing hormone (GnRH - PGF2 $\alpha-\mathrm{GnRH})$ was re-administrated. Insemination was carried out 16-24 hours after the last treatment without detection of heat, or after detection of it (OvSynch scheme).

The cows of the second experimental group were iadministrated intramuscularly with a synthetic analogue of the gonadotropic releasing hormone "Surfagon" at a dose of $2 \mathrm{ml}$, and after 7 days - the analogue of prostaglandin PGF2 $\alpha$ "Estrofantin" (GnRH - PGF2 $\alpha$ ) according to the SelectSynch scheme.

After the treatment, the blood was taken from the cows of the first and second groups for testing the level of hormones (table 4).

Table 4. Results of the tests of the level of hormones in the blood of cows after the use of treatment regimens.

\begin{tabular}{|c|c|c|c|c|c|}
\hline Values & $\begin{array}{c}\text { FSH } \\
(\mathbf{m I U / L})\end{array}$ & $\begin{array}{c}\text { LH } \\
(\mathbf{m I U / L})\end{array}$ & $\begin{array}{c}\text { Progesterone } \\
\text { (nM/L) }\end{array}$ & $\begin{array}{c}\text { Эстрадиол } \\
\text { (пмоль/л) }\end{array}$ & $\begin{array}{c}\text { Testosterone } \\
\text { (nM/L) }\end{array}$ \\
\hline $\begin{array}{c}\text { The first roup } \\
\text { (regimen } \\
\text { OvSynch) }\end{array}$ & $13,6 \pm 1,00^{*}$ & $11,6 \pm 0,56^{*}$ & $1,9 \pm 0,34^{*}$ & $135,5 \pm 1,42^{*}$ & $0,95 \pm 0,08^{*}$ \\
\hline $\begin{array}{c}\text { The second } \\
\text { group (regimen } \\
\text { SelectSynch) }\end{array}$ & $12,8 \pm 0,88^{*}$ & $10,3 \pm 0,13$ & $1,7 \pm 0,25^{*}$ & $110,5 \pm 1,26^{*}$ & $0,95 \pm 0,02^{*}$ \\
\hline $\begin{array}{c}\text { Reference } \\
\text { range }\end{array}$ & $11,4-15,0$ & $10-12$ & $2,0-3,0$ & $110-116$ & $0,9-1,5$ \\
\hline
\end{tabular}

Statistically significant at level of significance of $\mathrm{p}<0.05$

After the using of drugs according to the treatment regimens, the content of folliclestimulating, luteinizing hormones, progesterone, estradiol, and testosterone reached the physiological norm in the experimental groups.

When carrying out insemination, the following results were obtained. 
In the first group (OvSynch scheme), $75 \%$ of the total number of treated animals came into heat, $25 \%$ of animals did not show signs of heat, but all animals were found to be pregnant on30-45 days .

In the second group (SelectSynch scheme), $60 \%$ of the total number of treated animals came into heat, $40 \%$ of the animals did not show any signs of heat, all animals were pregnant for 30-45 days.

To normalize the hormonal status and stimulate the sexual heat of sows, the drugs "PG $600 "$ and "Follimag" were used, they affect the growth and development of follicles and their ovulation in females.

"PG-600" is a combined hormonal preparation manufactured in the Netherlands, containing as active ingredients $400 \mathrm{IU}$ of pregnant mare serum gonadotropin (PMSG) and 200 IU of human chorionic gonadotropin (hCG). Serum gonadotropin stimulates the development of follicles, and chorionic gonadotropin promotes ovulation and the formation of the corpus luteum. The combination of these hormones contributes to the development of full reproductive cycles in pigs.

Follimag is a domestic drug containing gonadotropic hormone in the blood serum of pregnant mares (PGH), purified from immunogenic proteins - $500 \mathrm{IU} /$ vial and $1000 \mathrm{IU} /$ vial. PFSA has both follicle-stimulating and luteinizing activity and does not have crossspecies specificity.

Sows of the first experimental group were administrated intramuscularly once with the preparation "PG-600" in 1 dose / head, which contains $400 \mathrm{IU}$ of gonadotropin of pregnant mare serum (PMSG) and $200 \mathrm{IU}$ of human chorionic gonadotropin (hCG).

Sows of the second experimental group were administrated intramuscularly with a single administration of the drug "Follimag" 1 dose / head, containing 500 IU of gonadotropin in the blood serum of pregnant mares.

On the 6th day after the administration of the drugs, blood tests were taken from pigs of both experimental groups to study their effect on the hormonal status of sows (table 5).

Table 5. Results of blood tests of sows for the level of hormones on the sixth day of treatment.

\begin{tabular}{|c|c|c|c|c|c|}
\hline Values & $\begin{array}{c}\text { FSH } \\
(\mathbf{m I U} / \mathbf{L})\end{array}$ & $\begin{array}{c}\mathbf{L H} \\
(\mathbf{m I U} / \mathbf{L})\end{array}$ & $\begin{array}{c}\text { Progesterone } \\
(\mathbf{n M / L )}\end{array}$ & $\begin{array}{c}\text { Эстрадиол } \\
\text { (пмоль/л) }\end{array}$ & $\begin{array}{c}\text { Testosterone } \\
(\mathbf{n M} / \mathbf{L})\end{array}$ \\
\hline The first group & $14,1 \pm 1,3^{*}$ & $12,2 \pm 1,2^{*}$ & $33,2 \pm 2,7^{*}$ & $85,3 \pm 13,4^{*}$ & $0,95 \pm 0,06^{*}$ \\
\hline The second group & $13,2 \pm 1,3^{*}$ & $11,3 \pm 1,2^{*}$ & $33,5 \pm 2,7^{*}$ & $83,3 \pm 11,2^{*}$ & $0,91 \pm 0,14^{*}$ \\
\hline Reference range & $12-15$ & $9-13$ & $34-36$ & $76-89$ & $0,9-1,2$ \\
\hline
\end{tabular}

${ }^{*}$ Statistically significant at level of significance of $p<0.05$

After using of the preparation "PG 600" in animals of the first experimental group, an increase in the level of follicle-stimulating hormone by $35.05 \%$, luteinizing hormone - by $42.86 \%$, progesterone - by $1.03 \%$, estradiol - by $14.77 \%$ was observed.

In the second experimental group, the using of the drug "Follimag" caused an increase in the level of follicle-stimulating hormone by $28.41 \%$, luteinizing hormone - by $28.40 \%$, progesterone - by $1.27 \%$, estradiol - by $13.64 \%$.

Testosterone levels in both groups remained within the physiological norm.

After the administration of "PG 600" and "Follimag" on the 6th day, the sows were inseminated, regardless of the presence of signs of sexual heat.

Table 6. Research results after the use of drugs.

\begin{tabular}{|l|c|c|c|c|}
\hline \multirow{2}{*}{ Animal group } & \multicolumn{2}{|c|}{ Came to sexual heat } & \multicolumn{2}{c|}{ Insemination efficiency } \\
\cline { 2 - 5 } & $\begin{array}{c}\text { Number of } \\
\text { heads }\end{array}$ & $\boldsymbol{\%}$ & Number of heads & $\%$ \\
\hline Group № 1 & 4 & 80 & 5 & 100 \\
\hline Group№ 2 & 3 & 60 & 4 & 80 \\
\hline
\end{tabular}


In the group where the hormonal status was corrected with the "PG 600" preparation, 4 out of 5 sows came to sexual heat, which was $80 \%$. When the hormonal status was corrected with Follimag, 3 out of 5 sows came to sexual heat, which was $60 \%$.

Pregnancy was diagnosed on the 20 days after insemination by the rectal method using an ultrasound study. In the experimental group, where the preparation "PG 600" was used, the efficiency of insemination was $100 \%$ (pregnancy was established in all 5 animals in the group). And in the group where the drug "Follimag" was used, pregnancy was established in 4 sows out of 5 (insemination efficiency $80 \%$ ).

\section{Conclusions}

The conducted research allows us to draw the following conclusions:

- The intensification and concentration of production, the expansion of existing livestock enterprises with the introduction of modern industrial technologies on them is accompanied by chronic industrial stresses, which inevitably leads to a decrease in rate of fertilization and breeding power of animals, to a lengthening of the production cycle of livestock products, and, in general, to a decrease in the profitability of the industry.

- The use of hormonal stimulation in the first week after parturition causes the growth of follicles in the ovaries, leads to the activation of the sexual function of animals, makes it possible to achieve an earlier coming of sows and cows into heat and increase the percentage of their insemination.

- When studying the comparative effectiveness of the schemes for the use of hormonal drugs "Estrofantin" and "Surfagon" in cows with ovarian hypofunction, we were convinced that the greatest therapeutic efficacy is achieved when using the OvSynch scheme. After such a complex treatment, both the percentage of cows that have come into heat and the efficiency of their insemination increase up to $100 \%$.

- The study of the comparative effectiveness of the use of hormonal preparations "PG $600 "$ and "Follimag" in sows showed that the therapeutic efficacy with $100 \%$ efficiency of insemination is achieved when hormonal stimulation with the preparation "PG 600" is carried out.

\section{References}

1. T.M. Epishina, Animal husbandry, 2, 29, 2009

2. A. Lishchuk, N. Malakhova, O. Piskunova, IOP Conference Series: Earth and Environmental Science, 12, 46 (2019).

3. A. Lishchuk, N. Malakhova, O. Piskunova, IOP Conf. Series: Earth and Environmental Science 042041 IOP Publishing doi:10.1088/1755-1315/666/4/042041, 666 (2021).

4. O.S. Mityashova, I. V. Gusev, I. Yu. Lebedev, Metabolism and reproductive function in the postpartum period in first-calf cows with the introduction of placenta extract / // https://cyberleninka.ru/search?q=Animal+Reproduction+Science\&page=4\&cat_ids=2 (date of access 19.04.2021).

5. S.V. Moryakina V.A. Anzorov, Disorder of the reproduction function of cows of different breeds, Potential of modern science, 5, 40, 46 (2014).

6. A.G. Nezhdanov, K.A. Lobodin, G.P. Dyulger, Hormonal control over the reproduction of cattle, Veterinary Medicine, 1, 3-7 (2008).

7. K.V. Plemyashov, P.G. Zakharov, I.L. Suller, E.A. Oleksievich, Reproduction problems of cattle. Solutions. Tutorial, 16, 258 (2013). 
8. B.I .Protasov., II Komissarov, Strategy for the use of adaptogens to stimulate productivity in farm animals, Agricultural biology. Series Biology of animals 6, 12-23 (2012).

9. E.N. Tyurenkova, O.R. Vasilyeva, Feeding as the main factor in the productive longevity of a dairy cow, FarmAnimals, 2 (6), 100-110 (2014).

10. O.V. Shishkin, We control the process of herd reproduction, Pig breeding, 6, 90-91 (2016).

11. V.N. Ivanova, I.A. Nikitin, N.A. Zhuchenko, M.A. Nikitina, Y.I. Sidorenko, V.I. Karpov, I.A. Zavalishin, International Journal of Advanced Computer Science and Applications, 10 (2), 45-50 (2019) 